\title{
Starting Condition Problems in Collaboration of Lampung Province Central Government Displacement Policy
}

\author{
${ }^{1}$ MAULANA MUKHLIS, ${ }^{2}$ MUDIYATI RAHMATUNNISA, ${ }^{3}$ NENENG YANI YUNINGSIH \\ 1 Universitas Lampung, Sumantri Brojonegoro No. 1 Street, Bandar Lampung, Indonesia \\ ${ }^{23}$ Universitas Padjadjaran, Bukit Dago Utara No. 25 Bandung, Indonesia \\ email: ${ }^{1}$ maulanamukhlis1978@gmail.com; ${ }^{2}$ m.rahmatunnisa@unpad.ac.id; ${ }^{3}$ nenengyany@gmail.com
}

\begin{abstract}
Starting condition is a key factor in determining the success of collaborative governance in policy implementation. Operationally, starting condition is determined by aspects of power/resource balance, trust between collaborators, various types of incentives to encourage participation, and previous history of cooperation experiences or conflict from related parties in collaboration. This research aims to provide description and confirmation concerning the extent of starting condition related to the termination of Lampung province central government displacement policy. It is descriptive research using the inductive approach. Methods of data collection used are interviews, observations, and library study. Data are being analyzed qualitatively through steps of data reduction, data presentation, and drawing conclusion. The research result shows that three out of four aspects of starting conditions are not considered in starting the collaboration process of Lampung province central government displacement policy. There are harms in the forms of imbalanced power/resource, not-wholeheartedly participations, and distrust between collaborators. A pseudo-collaboration as the implication of problems in the starting condition factors is finally confirmed to the failure of collaboration or policy implementation.
\end{abstract}

Keywords: starting condition, collaborative governance, central government

\section{Introduction}

Collaborative government currently becomes one of the advanced models in the governance of Indonesian government. Being understood as a constructive cooperation by involving many actors in a formalized institution, the collaborative government is assumed to be able to manage public interest optimally by offering a more inclusive format and to open intensive interaction between state actors and private actors. The underlining argument for the importance of collaborative governance is that the government faces challenges both internally and externally in the governance process and public policy implementation.

Internally, the government cannot implement its functions optimally by only relying on its own resource ability. A study by (Goldsmith, Stephen and Eggers, William D 2004) shows that the government is not always having sufficient resources in facing public problems so that it requires an alliance between the government and other parties, even cross-sectoral alliances if it has to. This internal condition is also aggravated by the high sectoral ego covering most of the public institutions. The appropriate solution to overcome both structural and sectoral ego problems is collaboration (Killian, 2012) economic diplomacy becomes the most important instrument for countries, and hence the (in. Externally, there is a fact that the policy environment outside the government always changes and shifts dynamically. This change/ shift can be in form of an issue which extending into an abnormal direction, the increasing forms and numbers of actors of policy, the increasing capacities owned by actors outside the government, and the increasing responses and initiatives of public (Sudarmo, 2009).

It is not exaggerating when (O'Leary,

Received: 2018-04-10, Revised: 2018-11-23, Accepted: 2019-05-28

Print ISSN: 0215-8175; Online ISSN: 2303-2499. DOI: http://dx.doi.org/10.29313/mimbar.v35i1.3667

Accredited Sinta 2 based on the decree No.10/E/KPT/2019 until 2024. Indexed by DOAJ, Sinta, Garuda, Crossreff, Dimensions 
Fulbright New Zealand, and Ian Axford (New Zealand) Fellowships in Public Policy 2014) makes collaborative governance as the most important choice to build the future of public policy in a state. (Kallis, Giorgos 2009) suggests collaborative government as adaptive management to ensure implementation of a program, while (Sorensen and Torfing 2012) places collaborative governance as a new idea and practical innovation as a strength in public sector implementation and in triggering a better policy-making process.

The collaborative governance implementation in varying countries and regions in Indonesia have been committed in particular policy practices. Studies by (Innes 2000) on Collaborative Governance in Clean Water Providing Program in California; (Sergio 2006) in The Water Resource Management Policy in Mexico; (Sranko 2011) in Forest Rescue Program in North Queensland; (Vij 2011) in Employment Protection Policy in India, (Indriati 2015) in Health and Education Field Development in West Java; and (Zaenuri 2014) on The Collaboration for Disaster Tourism Governance in Yogyakarta; all of them suggest that collaborative governance provides positive effects in the success of policy implementation as long as the key factors of collaborative governance can be fulfilled. It means that, the fulfillment or unfulfillment of collaborative governance key factors will determine either success or failure of policy objectives collaboration.

Lampung province government through Sjachroedin ZP governor in 2007 issued a policy for displacing the provincial center of government by building a new town in North Lampung district region. The scenario was that in 2014, the government center would be displaced from Bandar Lampung to the new location. This government central displacement was just the beginning and it was expected to encourage other nongovernmental sector activities such as housing, education, markets, etc (Bappeda Provinsi Lampung 2007), to follow the path. Some activities started from the formulation process to implementation in the Lampung province central government displacement was associated with Emerson's opinion (Ulibarri 2015) which referred to as activities carried out in collaborative governance. According to Emerson (Ulibarri 2015), the policy process which contains interactions between parties producing outcomes, agreements, and actions, is the core process and main component of the collaboration work frame.

Through a very dynamic process, the implementation of central government displacement was started in 2010 with a planning scenario to be finished in 2032. The initial investment of Rp. 3.1 trillion went smooth at the beginning, at least until 2014. The collaboration forum in the form of Planning Coordination Team (at the formulation stage) and Regional Management Agency (at implementation stage), the support of Government Regulation number 2 in 2013 concerning Kota Baru in Lampung, and the cooperation between parties were proven to be the driving process for the policy implementation process. However, it was changed at the end of 2014 when the election of Lampung governor was carried out. By the reason of limited regional budget, the policy implementation that had occurred for five years was terminated by newly selected Lampung governor, M. Ridho Ficardo, and it was no longer become a priority of development in The Middle Term Development Plan for Lampung Region in 2014-2019.

Based on conceptual base and empirical phenomena above, this research is important because of: (1) the termination of the Lampung province central government displacement policy also means the termination of the ongoing collaboration process; (2) collaborative governance approach which theoretically considered as a precise strategy in facing politicization of regulations, swelling and limited budgets, and implementation failure, was even unable to ensure its sustainability; (3) whereas the collaborative governance theory in the ideal sense imagined by its advocates to be related to good outputs is not something that will continue to run smoothly in Indonesia; at least in the case of termination of Lampung province central government displacement policy.

(Ansell, 2007) confirms that the success of collaborative governance is determined by three factors; starting condition, institutional design, and facilitative leadership as supporters of a collaborative process. To disagree with the limited budget as a classical reasoning used by the selected Lampung governor, M Ridho Ficardo, when he terminated the policy, the argument of Ansell \& Gash (2007) regarding the starting condition factors will be a starting point of this research to find out the extent of how the starting conditions influencing or having correlation with the 
termination of Lampung central government displacement policy.

The starting condition is an early condition before collaboration and it will determine whether the collaboration is successful or not. (Ansell 2007) focuses on four aspects or early condition variables need to be considered in starting condition. They are resource and power imbalance between actors, trust level between actors, previous history of collaboration experience or conflict between actors in previous collaboration, and urges or incentives to make them willing to participate and collaborate.

Resource imbalance occurs when the collaborators do not have any organizational or resource capacity to participate or there is a gap of power/resource between collaborators. The second aspect, equality between collaborators will affect internal confidence level and confidence level from one collaborator to another externally. Imbalanced power between collaborators will influence the exclusiveness of collaborators which then affects commitment and encouragement to participate. However, even though there is an imbalance, if there is still mutual dependency between collaborators, there will be a guarantee of participation with an assumption that the achievement of policy objective is, one of them, determined by other actors' roles. This concept is the meaning or analogy of dependency.

The third aspect of starting condition is previous history in form of cooperation or conflict experience. When each collaborator has capacity or experience in past relationship, it can minimize conflict intensity to be able to collaborate again, and vice versa. The last aspect of starting condition is incentive which should be considered prior to the formation of a collaboration forum. Incentives which are purposively needed to encourage participation are given in form of direct incentive (money or goods) or indirect ones such as prestige, pride, and other psychological aspects as suggested by (Olson, Mancur 2012).

\section{Research Methodology}

This research was designed as qualitative research. The qualitative method was selected because the researcher wanted to do exploration to understand, internalize, and explain how the aspects in starting condition influenced the termination of Lampung province central government displacement policy. Primary and secondary data were collected through methods explained by (Creswell 2015) including result data from observations, interviews, and documentation related to the dynamics of Lampung province central government displacement policy. Primary data came in the form of statements or information directly from the sources (informants) who became subjects and objects of this research, the. Secondary data were in the form of relevant documents collected from library and documentation study.

Informants were determined based on data needs and collaborator grouping in the occurring collaboration dynamics in Lampung province central government displacement policy. The data validation process was conducted by using triangulation; a method to examine data validation by using something outside the data themselves for checking or comparing the data (Wiersma, in Sugiyono, 2007). There are five types of triangulation: source triangulation, time triangulation, theory triangulation, researcher triangulation, and method triangulation; and this research used source triangulation, theory triangulation, and method triangulation for the validation process.

\section{Result And Discussion}

\section{Power and Resource Imbalance: First Finding}

Power/resource imbalance is the first aspect of starting condition before a collaboration is done to prevent manipulation and intervention from stronger actors. There are some explanations for this matter. (Ansell 2007) confirms the needs of (1) a representative organization or forum in the collaboration process; (2) the ability to negotiate; and (3) time and effort to participate in a collaboration.

In Lampung province, central government displacement policy, collaboration in the planning stage was conducted by organizations and represented by representatives of these organizations. Collaborators represented government, privates, public groups, and universities. A collaboration forum was legalized through the Decree of Lampung Governor number G/566/ II.01/HK/2009 concerning the Formation of Planning Coordination Team which consisted of Lampung province government elements ( 8 organizations of regional apparatus: the Head 
of Regional Development Planning Agency (Bappeda), the Head of Public Work, the Head of Transportation Office, the Head of Mining and Energy Office, The Head of Governance Bureau, the Head of Economy Bureau, the Head of Asset and Equipment Bureau, and Secretary of Bappeda); the Head of Bappeda in Bandar Lampung, the Head of Bappeda in South Lampung, the Head of Regional Office of National Land Agency in Lampung Province; President Director, Director of Human Resource and General Affairs, and General Manager of PT. Perkebunan Nusantara (PTPN) VII (Limited Company); the Chairman of Regional Representative Board of Indonesian Real Estate (representing privates), the Chairman of Planning Expert Association (IAP) in Lampung branch (representing public group), and the Chairman of Research Institution of Lampung University (university element).

The interview results showed that the composition of Planning Coordination Team membership was based on some considerations. First, the organizations were directly under the authority or regional development plan and then appointed 8 (eight) heads of working apparatus in Lampung province environment. Second, the organizations were estimated to be affected by the policy, so that Bandar Lampung and South Lampung district governments were appointed. Third, the organizations should be the precondition for the success of planning, so that PTPN VII (limited company) as the main stakeholders and DPD REI of Lampung as the supporting stakeholders were appointed. Fourth, organizations must have the competence to make plans, so that IAP of Lampung and an element from the university were appointed to represent considerations from this fourth criterion.

The consensus result in the planning stage was a mutual agreement concerning the provincial central government displacement. The answers related to the questions of where the location was, how, by whom, and when, would be stated in the master plan containing design agreement, role sharing agreement in the implementation stage, and agreement concerning the future location of new provincial central government (concerning land issue). This master plan would become a base or attachment for regional regulation that was specially drafted as a legal standing for this provincial central government displacement.

Scrutinizing result showed that aspects of power and resource imbalance between collaborators in the Planning Coordination Team were interesting to uncover. In general, all collaborators possessed power and resources as basic capitals for their involvement in the collaboration. Four considerations in determining actors that should be involved in the collaboration were proven to be precise in preventing a sharp power/resource imbalance. Despite those power and resources practically became capitals for building a final consensus in the planning stage, there was still domination of power and resource from one of the collaborators.

One of the consensuses from Planning Coordination team was the provision of land of $\pm 4,000$ hectares owned by PTPN VII (limited company) as the first priority for the location of the new provincial central government building. The implication of this consensus was that PTPN VII (limited company) became the most influential and powerful actor. That land became the main precondition because the plan design and objective for the land could only be drafted by the planning consultant after there was a certainty concerning the land location for the new provincial central government building. Unmitigatedly, the president director, general director, human resource director, head of technical division, to head of legal division of PTPN VII (limited company) were al directly involved in the Planning Coordination team. In the precondition context of policy implementation, PTPN VII (limited company) was the most powerful collaborator with the most resources in the planning period and it even became a determinant of the policy implementation sustainability.

A maximum resource was also owned by the Regional Development Planning Agency (Bappeda) of Lampung province as the secretary of Planning Coordination team, because it had an authority to regulate meeting agenda in the collaboration forum. Budget availability owned by Bappeda of Lampung province in the planning aspect proved that from a budgeting perspective, Bappeda was the most powerful with the most resources since all planning activities carried out by both Planning Coordination Team and third parties could be controlled by Bappeda. It was similar with other regional apparatus, such as Public Work Office and Transportation Office, in which they were collaborators with technical power and resources that other parties did not possess in the context 
of budgeting for other technical planning documents, for examples, those related to authorities of road and transportation development plan in newly provincial central government region.

When finally and verbally, the directors of PTPN VII (limited company) gave their consent to Lampung province government to use their land for a new provincial central government site, the power and resource dominations shifted into another actor. Technically, PTPN VII (limited company) did not have the required resource in technical planning. The Planning Coordination Team through a budget from Bappeda of Lampung province committed cooperation with third parties: PT Dwi Karsa Envacotama (a company stated in early master plan) and PT Visitama Daya Solusi (a company stated in revised master plan) to draft master plan documents for building the new Lampung province central government site. In the planning perspective, planning consultants had the most dominant power and resource compared to other actors. The involvement of Planning Expert Association (IAP) of Lampung in providing technical advises for planning consultants due to the reason that this institution had power and resource which technically able to provide second opinion to the planning documents being drafted.

In this planning stage, the most unseen actors for power and resources were Bandar Lampung and South Lampung governments. These two autonomous regions tended to be passive because technically they did not have authorities to be involved in planning. They also did not have preconditions and capacities to provide supports. Even though Natar and Jati Agung sub-district had been determined by the consensus of Planning Coordination Team to be the location of new provincial central government, and they were administratively under the South Lampung district region, the land management issue was not in the hand of South Lampung district government because it became the Cultivation Right Title (HGU) given to PTPN VII (limited company). Meanwhile, in the scenario, Bandar Lampung municipal government was positioned to receive grants of assets from ex-official buildings from Lampung province government; nevertheless, it did not show significant power other than supporting commitment as supporting facilities.

In the stage of policy implementation, the collaborators that formally joined the collaboration forum were members of Regional Management Agency which was formed based on the Decree of Lampung Governor number G/75/B.III/HK/2011. Interview results with former Lampung governor, Sjachroedin ZP, showed that this agency, in the beginning, was designed and expected to be able to function and has a role just like the "Batam Development Board Agency" autonomously. However, facts showed that during the process, this forum of collaboration was not autonomous at all because budget for the activities relied on budget from Bappeda of Lampung province. In this dependency context, the role of Bappeda of Lampung province was very dominant in controlling power and resource upon the sustainability of collaboration process in the policy implementation stage. Meanwhile, the knowledge transition from Planning Coordination Team to the Regional Management Agency was very good because all of produced planning documents, obtained consensus, and resources owned by Planning Coordination team became the rights of the Regional Management Agency at this implementation stage.

Power and resource in implementation stage still indicated imbalance, especially in period of 2010-2012, in which at the early consensus, the land owned by PTPN VII (limited company) would be used as the location of government offices. Other actors could do nothing but waiting for the result of land right transfer process in the Ministry of State Owned Enterprise as the Chief Financial Officer and Chief Operating Officer with a land acquisition scheme referring to provisions in Regulation of Minister of State Owned Enterprise number 2 in 2010 concerning Procedure of Writing Off and Transfer of Fixed Asset of State Owned Enterprise. The power and resource owned PTPN VII (limited company) was very powerful and influential to the success of all agendas behind the provincial central government displacement.

In the period of 2010-2012, maximum power and resource were still owned by other private actors. The land concession would be given to some investors, such as companies from Malaysia, South Korea, and Lippo Groups. They became actors with powerful power and resource because the state position (Lampung province government) would be a party receiving the results of center offices region developments that become responsibilities of these private parties. Furthermore, the plan design that had been 
made by planning consultants and approved by Planning Coordination Team, or that had been provisioned by Lampung governor, could be modified according to the interests of these private parties. These facts indicated that the state actor position was lower than private actor position, the party who would build the Lampung central government site.

The situation concerning power and resource absolutely changed when in 2012, the Lampung governor, Sjachroedin ZP, decided to abandon the land location owned by PTPN VII (limited company) as the candidate of office center location and moved into forest land under the authority of Ministry of Environment and Forestry. The implementation of provincial central government displacement was delayed because of planning document revisions as the implication of moving to the new location. The power and resource that was previously owned by PTPN VII (limited company) shifted into the Ministry of Environment and Forestry. Knowing this change, the investors made up their minds and decided to stop investing. The scenario where investors would build the provincial central government on concession land which would also be developed as commercial location was terminated. The Lampung governor, Sjachroedin ZP, was angry and the implication was that the plan for office development that would be started in 2012 was transferred to local government offices, not depending on the investor funding anymore.

In the negotiation ability aspect, knowledge was the most important precondition. In the planning stage, knowledge of parties involved in the collaboration was undoubted. The fact showed that during planning process in 2007-2010, there was a balanced knowledge sharing represented by members in the Planning Coordination Team with their competence and ability including knowledge concerning substances of policy being planned.

In the third aspect, time and effort availability were important factors in collaboration sustainability. In the stage of drafting the master plan, the presence of members of Planning Coordination team was important because it was related to agreement to be made, even though this was not an absolute requirement. The roles of Bappeda of Lampung province as the secretary of Planning Coordination Team and Region Management Agency were very significant in the meetings. These meetings were not only aimed to reach consensus internally inside the Planning Coordination Team, but also important for meetings between Planning Coordination Team and outside actors who were not involved directly in collaboration forum.

While the team activities were mostly meetings in the planning stage, in the implementation stage they had to employ time and effort availabilities which equal to power and resources they had based on their shared roles and responsibilities. Regarding time and effort availabilities, there was a significant difference before and after 2012 when the location of office center development was moved. Before 2012, forums held by Planning Coordination Team and Region Management Agency were attended by most team members because there were high mutual dependencies between them. However, after the location design was moved to the forest land owned by Ministry of Environment and Forestry, the domination of resources, time, and efforts were shifted to actors from state (Lampung government province and Ministry of Environment and Forestry as the institution having permit to release the forest land).

In some cases, power and resource of the state were lower than the private's. However, in the other side, the state could be more powerful because it had the authority. Power and resources owned by state actors were absolute because they have the required authority for budgeting, while power and resources owned by non-state actors were purely because they had capacities or skills. In this position, the imbalance power and resource between actors could be seen in the Lampung province central government displacement policy.

An illustration concerning power and resources between collaborators that caused imbalance can be seen in the figure 1 .

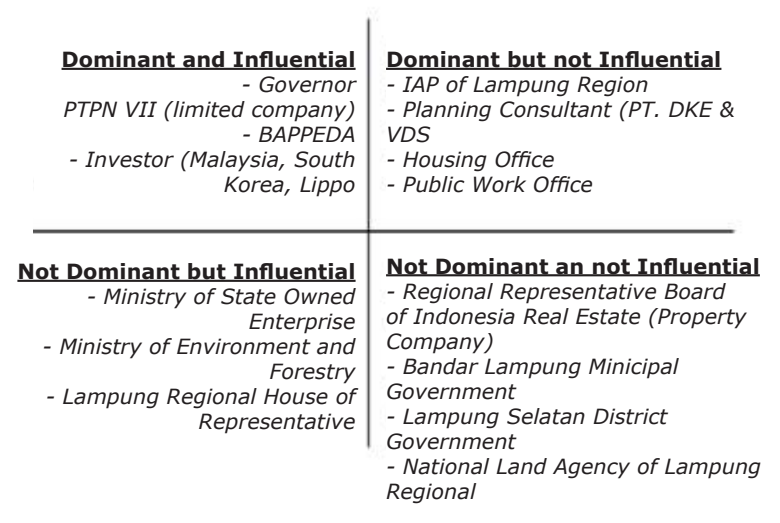

Figure 1. Mapping of Power and Resource 


\section{Domination between Actors \\ Incentives for Not Wholeheartedly Participations: Second Finding}

Incentives for collaborators to participate would be depending on their expectations whether the collaboration process would produce something meaningful, especially to the balance between time and efforts they had been provided compared to outcomes they would receive. Therefore, the main issue needed to consider was what kind of incentive the collaborator would get from the collaboration. However, ideally, the collaborator's participation should be coming from voluntary deeds based on an awareness that public issues should be of shared concern. Therefore, whether there were incentives or not, ideally, they should not influence the collaboration success factors.

At the previous part, it has been explained that involvement of actors in the collaboration was categorized into two groups. First, the actor group who collaborated because of obeying order, especially actors coming from regional government institutions; and second, the actor group who collaborated because of factor of interest. This interest, of course, had some meanings: in addition to the interest based on an awareness that the actor's contribution in the team was a part of participation in regional development, the actor involvement also expected certain objectives, for example, the objective of PTPN VII (limited company) was to maintain its plantation assets and stability of the company revenue.

The meaning of an objective or interest was closely related to the incentive. The incentive given as the participation encouragement would be lower when the collaborator was able to achieve its objective and outcome unilaterally upon that collaboration. Oppositely, the incentive to participate would increase when the collaboration process in an inclusive forum to make mutual decision included no particular objective from the collaborator to participate. The research result showed that there was almost no special incentive given to the collaborators upon their participation in the team, both during planning and implementation, except a monthly fee of approximately Rp.400,000 that was deducted with $15 \%$ income tax (PPh). However, this incentive meant nothing compared to benefits the actors would receive through their involvements in the team, for example, what
PTPN VII (limited company) would receive upon the collaboration.

Concerning the not-wholeheartedly participations, in fact, this is in line with (Olson, Mancur 2012) who suggests the types of incentives that may be given in order to encourage collective action. An incentive is used to encourage an individual and to mobilize a group to follow an action. The incentive types can be in the form of prestige, respect, friendship, or other psychological purposes. In addition, there are also selective incentive in forms of sanction and reward. The incentives to encourage participations in the collaboration, both in the planning stage and implementation of Lampung province central government displacement policy, seemed to be in line with incentive types suggested by Olson.

If these incentive types which in line with Olson's perspective were mapped, then the selective incentive was in the form of reward given to all collaborators, especially to planning consultants who purposively paid to draft master plan documents and their derivatives. Prestige and respect incentives were obtained by Planning Expert Association (IAP) of Lampung and PTPN VII (limited company). All collaborators from regional government offices and institutions representing Lampung province government obtained friendship incentive in maintaining harmonization and obedience in the government administration.

Another question came up: why individual who did not get incentive or anything was willing to participate in a long term and strategic policy? (Olson, Mancur 2012) answer suggests an indication of a motive or interest as a clue. In some cases, clear or hidden interests were able to overcome the amount of incentives the actors received from participation. It was because without participation, not only their interests would reach nothing, but even more, they would get loss. Therefore, participation, in some cases, were modes to save actors' interests.

\section{Dissatisfied Mutual Trust: Third Finding}

Mutual trust between collaborators is very important in the collaboration process, referring to (Vangen, 2003) opinion stating that trust is understood as an expectation toward another party's behavior in the future related to a purpose. Trust between 
collaborators is influenced by shared understanding toward a purpose, information transparency, and collaborators' consistencies toward a consensus that has been agreed upon, so that there will be no opportunistic behavior from collaborators (Qu 2013). An opportunistic behavior at the end leads to the collaboration that seems to cooperate, but essentially each party only wants to achieve their particular purposes (Jones, Pip 2009). The trust can be formed based on expectation in the future and on historical perspective. Trust is also seen as a mechanism to reduce opportunistic behavior from other parties. Mutual trust between collaborators becomes an absolute factor in collaboration and an argument that should be explained before selecting parties for a collaboration. Distrust from one actor to another will lead the same distrust from other actor.

Bringing up mutual trust can be obtained by, one of them, assessing carefully experiences of actors' cooperation histories of activities in the past. This is important because (Ansell 2007) confirms that past history and good experience in forms of antagonism (conflict history) and cooperation can either inhibit or facilitate the ongoing collaboration. Thompson (in (Rahim 2001) states that a conflict occurs because of perceptions of interests between persons that are unable to reconcile due to mutual distrust. Thompson's opinion shows that conflicts in collaboration will always occur because of distrust between actors, and this causes incapability of a collaboration to achieve the objectives optimally.

The research result showed that historical base or experiences of parties in the collaboration were not considered. Four considerations in determining the actors to be involved were: (1) the organization was related directly to the authority in the regional development planning; (2) the organization was assumed to be affected by the policy; (3) the organization had a precondition for planning success; and (4) the organization had a competence to draft plans. These four arguments proved that factors of experience and past history concerning an organization or representative of an organization, whether they were ever involved in collaboration or collaboration conflict, were never becoming determinants or considerations. Concerning distrust between collaborators that implied to a conflict, different conditions occurred in the collaboration forum during planning and implementation processes. In general, conflicts in these processes could not be understood as a latent distrust situation, but only arguments and expression of different interests from each collaborator in the efforts to maintain their interests because each party had different perspective and interest in the collaboration forum.

In the planning stage, even though all Planning Coordination Team members agreed to a consensus that the land owned by PTPN VII (limited company) was selected as the location, the provincial central government displacement as a beginning center of driver, mechanism of private involvements and concessions given to them, and agreement upon the plan for time of policy implementation, but the design issues became pro and cons to be discussed in the team. Provincial government and Regional House of Representative of Lampung province argued that the model for provincial central government development as it was done in Putra Jaya Malaysia without "cut and file" was worthy to use by maintaining land contour in the land owned by PTPN VII (limited company). Meanwhile, the Planning Expert Association (IAP) of Lampung argued that the use of model without "cut and file" could not be done concerning the flood risk and puddles in some parts of the land owned by PTPN VII (limited company) that became the location candidate for the provincial government offices.

In the implementation stage, the conflict situations were hidden and unseen clearly between collaborated parties. The situation of Regional Management Agency was solid, so that its members expressed the same voice when facing interests of other parties outside the team. Some debates occurred, including when the Malaysian investor demanded a land concession outside the location of center of government offices for the commercial investment they would do. At the beginning, Malaysian investor did not openly explain the investment types they would do, even though finally it was stated that they would use the concession land to plant oil palm. This investment type was strongly refused by members of Regional Management Agency and Lampung provincial government because it did not support and was not related clearly to the long-term objectives of the Lampung provincial central government displacement policy.

The research result showed that some conflict examples caused by different perspectives among collaborators could 
be resolved by dialogue in the forum. The differences of interest between actors outside the forum were settled by excluding them in the ongoing policy implementation. However, the collaboration was a cycle depending on its previous cycle. Conflicts in term of different perspectives or even different interests could became a pre-condition for the creation of collaboration; if every party felt the mutual dependency to another, then the party's interest could be obtained. (Ansell 2007) confirms that if there is any antagonism of pre-history between collaborators, the collaboration will not be successful unless there high mutual dependencies and positive steps to recover the low trust level between collaborators.

Some findings in the implementation stage indicated many disappointments between collaborators. PTPN VII (limited company) was disappointed with Lampung province government because 350 hectares of the land that had been granted with an agreement to be used as provincial central government were granted by Lampung province government to Bandung Institute of Technology (ITB) to build Sumatera Institute of Technology (ITERA) campus in Lampung. Lampung province government was disappointed with investors (especially Malaysian investor) because they determined investment types as they wished without direct contributions to the substances of provincial central government displacement policy. South Korean investor was disappointed with Lampung province government because it failed to provide time certainty of when the land location would be finished. Internally, the Lampung governor, Sjachroedin ZP, was very disappointed with his bureaucracy apparatus because they were unable to fully implement the policy and his instructions.

These disappointments even though did not lead into conflicts, in fact reduced the trust level between collaborated actors. In the collaboration perspective, mutual distrust was a big challenge that must be resolved, one of them, by assessing the dependency level. According to Ansell and Gash (2007), collaborative governance will only able to work optimally if the collaborators consider themselves mutually dependent. Concerning this, the condition occurring in the collaboration in both planning stage and implementation stage of provincial central government displacement policy still indicated mutual dependency. The positive implication was that even though there were different opinions, or even more disappointments, the collaboration process was still able to carry out because there were mutual dependencies. In this perspective, the solution from (Ansell 2007) is precise.

\section{Conclusions}

Starting condition is one of key factors that determine success of collaborative governance which measured into the aspect of power and resource equalities, incentives as source and encouragement of participations in the collaboration, trust level between collaborators, and pre-history concerning cooperation or conflict. The research results showed that three out of four aspects in starting condition were proven to be not seriously considered in Lampung provincial central government displacement policy. The experience factor of institutional or individual to be involved in the collaboration did not become a determinant or taking into consideration. Even though the main reason used by agenda setters in developing actors' involvements was factors of resource or power possession, however, despite each actor possessed their own power and resource to collaborate, there were still imbalances of those power and resources. In a particular case, the power and resource owned by actors from the state lose compared to the ones owned by privates. The power of actors from the state seemed to be absolute only because they had authorities, not because they had capacities and technical resources. The implication was that during the collaboration process, many actors were disappointed, even though the disappointments did not lead to conflicts. These disappointments reduced the trust level between actors. Distrust situation came into the peak when the provincial central government displacement policy was terminated at the change of Lampung governor. Arguments and rationales of the termination were not all delivered clearly and completely to public and it became a factor that also confirmed the distrust situation.

The only thing encouraging the collaboration process continuity was either motive or interest, even though factually the incentives received seemed to be not wholeheartedly. In this context, collaboration was only an instrument to be used in a strategy for achieving a certain purpose or interest. This purpose could be in form of economy or political interest. To achieve it, one actor must depend on another actor. The empirical story presentation during the collaboration process 
in Lampung provincial central government displacement policy led into an understanding that collaboration could be considered as a vehicle to achieve economic interest so that collaborators agree to be tactical. Therefore, the starting condition problems proved to be insignificant to influence the collaboration process in the Lampung provincial central government displacement policy. The three precondition aspects of starting condition might be dissatisfied, but it did not immediately terminate the collaboration as long as there was a belief from collaborators that they still have potentials to realize their motives or interests.

\section{References}

Ansell, Chris and Gash. (2007). "Collaborative Governance in Theory and Practice." Oxford University Press 543-571.

Bappeda Provinsi Lampung. (2007). "Master Plan Pembangunan Kota Baru Lampung."

Creswell, John W. (2015). Penelitian Kualitatif \& Desain Riset, Memilih Diantara Lima Pendekatan. 3rd ed. Yogyakarta: Pustaka Pelajar.

Goldsmith, Stephen and Eggers, William D. (2004). "Governing by Network." Washington DC: Brookings Institusion Press.

Indriati, Jatti. (2015). "Kolaborasi Dalam Pembangunan Daerah Di Jawa Barat (Studi Kontribudi CSR Bidang Kesehatan Dan Pendidikan."

Innes, dkk. (2000). Collaborative Dialogue as a Policy Making Strategy. Berkeley: Institute of Urban and Regional Development University of California.

Jones, Pip. (2009). Pengantar Teori-Teori Sosial: Dari Teori Fungsionalisme Hingga Post-Modernisme. Jakarta: Yayasan Obor Indonesia.

Kallis, Giorgos. (2009). Collaborative Governance and Adaptive Management. Jurnal of Enviromental Science and Policy. Elsevier.

Killian, P M Erza. (2012). "Paradigma dan Problematika Diplomasi Ekonomi Indonesia." (2): 16.

O'Leary, Rosemary, Fulbright New Zealand, and Ian Axford (New Zealand) Fellowships in Public Policy. (2014). Collaborative Governance in New Zealand: Important Choices Ahead.

Olson, Mancur. (2012). The Logic of Collective Action: Public Goods and The Theory of Groups. America: Harvard University
Press.

Qu, Loosemore. (2013). "A Meta-Analysis of Opportunistic Behaviour in PublicPrivate Partnership: Manifestations and Antecedents: . Proceeding." Association of Researchers in Construction Management: 415-24.

Rahim, M. Afzalur. (2001). Managing Conflict in Organizations. 3rd ed. Westport, Conn: Quorum Books.

Sergio, Graf Montero. (2006). 18 Collaborative Governance for Sustainable Water Resources Management: The Experience of the Inter-Municipal Initiative for The IIntegrated Management of the Aquila River Basin Mexico. Published by International Institute for Environmental and Development (IIID).

Sorensen, Eva, and Jakob Torfing. (2012). "Collaborative Innovation in The Public Sector." The Public Sector Innovation Journal 17: 1-14.

Sranko, George R. (2011). "Collaborative Governance and a Strategic Approach to Facilitating Change: Lessons Learned from Forest Agreements in South East Queensland and the Great Bear Rainforest." Collaborative Governance 3: 30.

Sudarmo. (2009). "Elemen-Elemen Collaborative Leadership Dan HambatanHambatan Bagi Pencapaian Efektivitas Collaborative Governance." Jurnal IImu Administrasi FISIP Universitas Negeri Sebelas Maret 5: 100-112.

Sugiyono. (2007). Metode Penelitian Kualitatif, Kuantitatif Dan RD. Bandung: Alfabeta.

Ulibarri, Nicola. (2015). "Tracing Process to Performance of Collaborative Governance: A Comparative Case Study of Federal Hydropower Licensing: Ulibarri: A Comparative Case Study of Federal Hydropower Licensing." Policy Studies Journal 43(2): 283-308.

Vangen, Siv, Huxham, Chris. (2003). "Enacting Leadership for Collaborative Advantage: Dilemmas of Ideology and Pragmatism in the Activities of Partnership Managers." British Journal of Management 14: 61-76.

Vij, Nidji. (2011). "Collaborative Governance : Analysing Social Audits in MGNREGA in India." Institute of Development Studies (IDS) Oxford 14.

Zaenuri, Muchamad. (2014). "Mengelola Pariwisata-Bencana: Perlunya Perubahan Paradigma Pengeloaan Pariwisata Dari Adaptive Governance Menuju Collaborative Governance." Unisia 36 (81): 157-68. 